\title{
ANALISIS KEMAMPUAN DASAR MAHASISWA MENGGUNAKAN METODE DEMONSTRASI PADA MATA KULIAH METODOLOGI PEMBELAJARAN MATEMATIKA UNTUK ANAK USIA DINI
}

\author{
Gita Noveri Eza \\ Dosen Program Studi PG PAUD FIP UNIMED \\ Jl. Williem Iskandar Pasar V Medan Estate, Medan, Sumatera Utara,20371 \\ Email: gitanoverieza@unimed.ac.id
}

\begin{abstract}
Abstrak: Penelitian ini dilakukan di Program Studi PG-PAUD pada mahasiswa semester ganjil tahun ajaran 2016/2017. Penelitian ini bertujuan untuk mendapatkan gambaran mengenai kemampuan dasar mahasiswa Program Studi PG-PAUD dalam menggunakan metode demonstrasi pada Mata Kuliah Metodologi Pembelajaran Matematika untuk Anak Usia Dini. Jenis penelitian ini merupakan penelitian deskriptif kuantitatif dengan subjek penelitian adalah seluruh mahasiswa PG-PAUD yang mengambil Mata Kuliah Metodologi Pembelajaran Matematika untuk Anak Usia Dini. Teknik pengumpulan data dilakukan dengan cara observasi, wawancara, dan dokumentasi. Data kemudian diolah dengan statistik deskriptif untuk mendapatkan hasil berupa persentase. Penelitian ini diharapkan dapat dijadikan salah satu acuan dalam meningkatkan kemampuan mahasiswa menggunakan metode demonstrasi pada pembelajaran matematika anak usia dini. Hasil yang diperoleh berdasarkan observasi mahasiswa adalah $77 \%$ untuk persiapan dan dikategorikan baik, pelaksanaan $64 \%$ dikategorikan cukup, dan evaluasi 69\% dengan kategori baik. Secara keseluruhan kemampuan mahasiswa melakukan metode demonstrasi adalah $70 \%$ dan dikategorikan baik. Secara umum mahasiswa sudah mampu melaksanakan metode demonstrasi di kelas sesuai dengan langkah yang telah ditetapkan.
\end{abstract}

Kata kunci: anak usia dini, metode demonstrasi, pembelajaran matematika.

\section{Pendahuluan}

Matematika merupakan hal yang sangat penting dalam kehidupan kita. Dalam kesehariannya, manusia selalu menggunakan matematika untuk menghitung, mengukur, dan sebagainya. Oleh karena itu, matematika perlu dikenalkan sejak dini kepada anak. Matematika memiliki bermacam komponen yang bisa dikenalkan sesuai dengan karakteristik masingmasing anak.

Pembelajaran matematika untuk anak usia dini sangat diperlukan untuk mempersiapkan anak melanjutkan pendidikan dasar. Pengetahuan guru tentang pengembangan kemampuan matematika anak dapat dilihat dari kemampuan anak dalam mengenal konsep matematika sederhana. Dalam hal ini aspek yang diukur seberapa mampu guru tersebut mengembangkan kemampuan matematika anak melalui berbagai macam teknik dan metode. 
Salah satu metode yang bisa digunakan dalam pembelajaran matematika untuk anak usia dini adalah metode demonstrasi. Menurut Djamarah (2000), metode demonstrasi adalah metode yang digunakan untuk memperlihatkan suatu proses atau cara kerja suatu benda yang berkenaan dengan bahan pelajaran. Metode ini adalah salah satu metode mengajar dengan menggunakan suatu alat peraga disertai penjelasan lisan untuk memperjelas pengertian atau menunjukkan suatu proses tertentu kepada peserta didik.

Berdasarkan hasil penelitian Sartinem (2014: 68) metode demonstrasi dapat meningkatkan pemahaman peserta didik dalam memahami konsep pengurangan. Sejalan dengan hasil penelitian Cahyani (2015: 9) yang menyatakan bahwa penerapan metode demonstrasi dapat meningkatkan perkembangan kognitif anak. Jadi, dapat disimpulkan bahwa dalam pembelajaran matematika untuk anak usia dini, metode ini tepat digunakan untuk mengenalkan konsep matematika sederhana seperti konsep bilangan, geometri, dan lain-lain.

Sebagai seorang calon guru PAUD, untuk mengenalkan konsep matematika sederhana kepada peserta didik, mahasiswa dituntut mampu menggunakan metode demonstrasi ini agar aspek perkembangan kognitif peserta didik khususnya matematika dapat berlangsung secara optimal. Oleh sebab itu, perlu dilakukan penelitian untuk menganalisis sejauh mana kemampuan dasar mahasiswa PG-PAUD melakukan pembelajaran matematika dengan menggunakan metode demonstrasi untuk anak usia dini, terutama mahasiswa semester 3 (tiga) yang belum memiliki pengalaman melakukan pembelajaran untuk anak usia dini.

\section{Kajian Teori}

Pembelajaran matematika untuk anak usia dini sangat diperlukan untuk mempersiapkan anak melanjutkan pendidikan dasar. Pengetahuan guru tentang pengembangan kemampuan matematika anak dapat dilihat dari kemampuan anak dalam mengenal konsep matematika sederhana. Dalam hal ini aspek yang diukur seberapa mampu guru tersebut mengembangkan kemampuan matematika anak melalui berbagai macam teknik dan metode.

Salah satu metode yang bisa digunakan dalam pembelajaran matematika untuk anak usia dini adalah metode demonstrasi. Menurut Djamarah (2000), metode demonstrasi adalah metode yang digunakan untuk memperlihatkan suatu proses atau cara kerja suatu benda yang berkenaan dengan bahan pelajaran. Metode ini adalah salah satu metode mengajar dengan menggunakan suatu alat peraga disertai penjelasan lisan untuk 
memperjelas pengertian atau menunjukkan suatu proses tertentu kepada peserta didik.

\section{Metode Penelitian}

Penelitian ini termasuk penelitian deskriptif kuantitatif dengan subjek penelitian mahasiswa semester III PG PAUD Universitas Negeri Medan Tahun Ajaran 2016/2017.

Populasi dalam penelitian ini adalah seluruh mahasiswa semester III Program Studi PG PAUD Universitas Negeri Medan Tahun Ajaran 2016/2017. Sampel dalam penelitian ini diambil secara acak untuk perwakilan dari setiap kelas populasi yang mengambil mata kuliah Metodologi Pembelajaran Matematika AUD.

Rancangan penelitian yang dilakukan adalah sebagai berikut ini:

1. Perencanaan

a. Menganalisis materi dalam kurikulum PAUD untuk menentukan materi yang akan digunakan dalam penelitian

b. Menentukan komponen dalam metode demonstrasi mahasiswa yang akan diteliti

c. Menyusun dan mempersiapkan instrumen penelitian

2. Pelaksanaan

a. Membagi mahasiswa menjadi 8 kelompok sesuai dengan tema pembelajaran di PAUD yaitu 4 kelompok terdiri dari 4 orang dan 4 kelompok lain terdiri dari 5 orang

b. Memberi pengarahan dan petunjuk mengenai penggunaan metode demonstrasi dalam pembelajaran

c. Melakukan kegiatan demonstrasi oleh mahasiswa

d. Melakukan observasi yang dilakukan oleh observer selama proses perkuliahan

3. Penyelesaian

a. Pengolahan data dan hasil penelitian

b. Menganalisis dan membahas hasil penelitian

c. Menarik kesimpulan

Data dalam penelitian ini diperoleh dari hasil observasi, wawancara, dan dokumentasi.Adapun pengumpulan data dilakukan dengan cara sebagai berikut.

a. Observasi

Teknik pengumpulan data ini dilakukan dengan cara melakukan pengamatan langsung terhadap sikap, perilaku, dan aktivitas mahasiswa selama kegiatan perkuliahan berlangsung. Observasi dilakukan oleh teman sejawat dan dosen yang bersangkutan. Observasi ini menggunakan instrumen berupa checklist untuk 
mengetahui sejauh mana kemampuan dasar mahasiswa melalui metode demonstrasi.

Responden hanya diminta memberikan tanda cek $(\sqrt{ })$ pada kriteria aspek yang sesuai dengan pengamatannya.

b. Wawancara

Kegiatan wawancara dilakukan terhadap dosen pengampu mata kuliah Metodologi Pembelajaran Matematika AUD dan mahasiswa yang mengambil mata kuliah Metodologi Pembelajaran Matematika AUD. Kegiatan ini dilakukan menggunakan instrumen berupa list pertanyaan yang telah dipersapkan sebelumnya.

c. Dokumentasi

Pengumpulan data dokumentasi dilakukan dengan pengambilan foto dan video selama perkuliahan berlangsung.

Hasil observasi aktivitas peserta didik didapatkan dengan cara menghitung jumlah mahasiswa yang melakukan aktivitas sesuai lembar observasi yang ada. Data tersebut dianalisis dengan teknik persentase yang dinyatakan oleh Sudijono (2005: 43) sebagai berikut:

$P=\frac{f}{N} \times 100 \%$

Keterangan:

$P=$ persentase aktivitas

$f=$ frekuensi aktivitas

$N=$ jumlah peserta didik

Kategori rata-rata kemampuan dasar menggunakan metode demonstrasi mahasiswa menurut Arikunto (2008: 231) adalah sebagai berikut:

$80 \%-100 \%=$ Sangat baik

$66 \%-79 \%=$ Baik

$56 \%-65 \%=$ Cukup

$40 \%-55 \%=$ Kurang

$30 \%-39 \%=$ Gagal

\section{Hasil Penelitian Dan Pembahasan}

\section{Hasil}

Penelitian dilakukan selama 3 hari pada tiap kelas yang berbeda. Data yang diperoleh diolah dengan teknik persentase. Hasil yang diperoleh dapat dilihat pada Tabel 1 berikut ini. 


\section{Penilaian}

\begin{tabular}{llccc}
\cline { 3 - 5 } No. & Aktivitas & $\begin{array}{c}\text { Ada } \\
(\%)\end{array}$ & $\begin{array}{c}\text { Tidak ada } \\
(\%)\end{array}$ & Kategori \\
\hline 1 & Persiapan & 77 & 23 & Baik \\
\hline 2 & Pelaksanaan & 64 & 36 & Cukup \\
\hline 3 & Evaluasi & 69 & 31 & Baik
\end{tabular}

Penelitian dilakukan terhadap 34 orang dari total 88 orang mahasiswa PGPAUD yang mengambil mata kuliah Metodologi Pengembangan Matematika AUD. Pengambilan sampel dilakukan secara acak dengan teknik random sampling. Dari 34 orang tersebut, 13 orang dari kelas Reguler A, 14 orang dari kelas Reguler B, dan 7 orang dari kelas Ekstensi 2015.

\section{Pembahasan}

Dari hasil pengamatan terhadap aktivitas mahasiswa di atas diketahui bahwa secara umum penggunaan metode demonstrasi oleh mahasiswa sudah cukup baik. Dari 3 aspek tahapan yang diamati, 2 aspek sudah tergolong baik. Sedangkan untuk tahap pelaksanaan, persentase mahasiswa yang melakukan kegiatan dengan baik hanya 64\% dan tergolong cukup yang artinya masih banyak mahasiswa yang belum melaksanakan tahapan pelaksanaan sesuai langkah yang sudah ditetapkan.

Menurut Hasibuan dan Mudjiono (2013: 31), tahapan metode demonstrasi dimulai dengan persiapan, pelaksanaan, dan evaluasi. Tahap persiapan terdiri dari penetapan tema dan tujuan kegiatan, persiapan alat dan bahan, serta pemusatan perhatian anak untuk memperhatikan kegiatan demonstrasi. Tahap pelaksanaan terdiri dari penjelasan langkah kegiatan oleh guru, memperagakan/mendemonstrasikan kegiatan kepada anak, membimbing anak melakukan kegiatan, membantu anak yang mengalami kesulitan, serta memotivasi anak agar berpartisipasi aktif selama kegiatan. Tahap evaluasi adalah tahap penilaian terhadap anak setelah melakukan kegiatan. Pada tahap ini guru melakukan tanya-jawab kepada anak didik tentang hal-hal yang dilakukan dan diperoleh selama melakukan demonstrasi. Tanya jawab dapat dilakukan saat pelaksanaan demonstrasi ataupun setelah kegiatan demonstrasi berlangsung.

Tahap persiapan terdiri dari beberapa aspek pengamatan. Pada aspek penetapan tema kegiatan, setiap mahasiswa memilih satu tema dari delapan tema pada Kurikulum 2013 PAUD sesuai dengan yang terdapat pada Permendikbud No. 146 Tahun 2014 yaitu: Diriku, Keluargaku, Lingkunganku, Binatang, Tanaman, Kendaraan, Alam Semesta, dan Negaraku. Berdasarkan tema yang dipilih, mahasiswa menentukan sendiri materi pembelajaran matematika yang akan didemonstrasikan untuk anak usia dini. Untuk aspek penetapan tujuan kegiatan demonstrasi, hanya 50\% 
dari keseluruhan mahasiswa yang melaksanakan tahapan ini. Hal ini berarti setengah dari keseluruhan sampel tidak menyampaikan tujuan kegiatan demonstrasi pada anak. Dari aspek persiapan alat dan bahan, secara garis besar yaitu $90 \%$ mahasiswa telah mempersiapkan semua alat dan bahan yang dibutuhkan selama proses demonstrasi. Akan tetapi, $41 \%$ mahasiswa tidak menyiapkan alat dan bahan cadangan untuk dipakai bila ada kerusakan atau alat yang tidak layak pakai. Dilihat dari aspek pemusatan perhatian anak, 74\% mahasiswa sudah mampu memusatkan perhatian anak dengan mengajak anak bernyanyi serta melakukan tanya jawab.

Pada tahap pelaksanaan, ada 7 aspek yang diamati selama observasi. Secara umum, pada tahapan ini persentase mahasiswa yang melakukan kegiatan demonstrasi sesuai langkah yang ditetapkan adalah 64\% dan dikategorikan cukup. Berdasarkan data yang diperoleh, 53\% mahasiswa menjelaskan langkah-langkah kegiatan kepada anak didik. Dari 53\% tersebut, hanya $10 \%$ yang ikut memperagakan kegiatan di depan anak didik. Umumnya mahasiswa hanya menjelaskan kepada anak apa yang akan dilakukan, tanpa memberi contoh bagaimana cara mengerjakannya sehingga anak menjadi bingung.

Pembelajaran bukan hanya menyampaikan materi sesuai dengan kurikulum, tetapi juga harus memperhatikan kondisi siswa, materi, fasilitas, strategi dan metode belajar demi kelancaran pembelajaran. Oleh karena itu teknik pembelajaran harus tepat dan sesuai dengan karakteristik materi dan kondisi siswa.

Sebagian mahasiswa menjelaskan bagaimana langkah-langkah kegiatan kepada anak didik, tetapi tidak memperagakan bagaimana cara kerjanya. Sebagian mahasiswa tidak menjelaskan langkah kegiatan dan langsung memperagakan, sehingga anak didik tidak mengerti apa yang dilakukan oleh gurunya. Diadaptasi dari Hasibuan dan Mudjiono (2013: 31) langkah kegiatan pada tahap pelaksanaan adalah guru menjelaskan langkah kegiatan, lalu memperagakan kegiatan tersebut di depan anak. Kemudian guru membimbing anak didik melakukan kegiatan yang sama seperti yang telah dicontohkan guru. Dari hasil observasi, diketahui bahwa langkahlangkah tersebut tidak dilakukan mahasiswa secara berurutan.

Dilihat dari tahapan evaluasi, umumnya mahasiswa telah melakukan kegiatan tanya-jawab kepada anak didik mengenai kegiatan yang telah dilakukan. Akan tetapi masih sedikit mahasiswa yang melakukan evaluasi terhadap pelaksanaan demonstrasi ini, sehingga tidak bisa diketahui apakah tujuan kegiatan demonstrasi yang telah ditetapkan tercapai atau tidak.

Berdasarkan hasil wawancara dengan mahasiswa PG-PAUD angkatan 2015 yang sedang mengambil mata kuliah Metodologi Pengembangan Matematika untuk Anak Usia Dini, mahasiswa umumnya sudah mengetahui apa yang dimaksud dengan metode demonstrasi dan manfaatnya dalam pembelajaran matematika untuk Anak Usia Dini. Akan 
tetapi, mahasiswa belum mengetahui apa tahapan yang dilakukan selama proses demonstrasi itu.

Hasil wawancara dengan dosen pengampu mata kuliah Metodologi Pengembangan Matematika untuk AUD juga menunjukkan pentingnya penggunaan metode demonstrasi dalam pembelajaran matematika untuk AUD. Hal ini disebabkan materi-materi matematika untuk AUD tidak bisa hanya dijelaskan saja, tetapi juga butuh dicontohkan dan diperagakan oleh guru. Oleh karena itu, penggunaan metode demonstrasi sangat diperlukan oleh mahasiswa PG-PAUD sebagai calon guru PAUD. Dengan adanya metode demonstrasi, anak didik akan aktif selama pembelajaran karena ikut terlibat dan berperan dalam pelaksanaan pembelajaran. Sejalan dengan pendapat Putra (2013: 109) yang mengatakan bahwa metode demonstrasi merupakan metode yang efektif karena membantu siswa mencari jawaban dengan usaha sendiri berdasarkan fakta atau data yang benar. Hal ini akan memudahkan pengembangan anak didik karena aktivitas yang melibatkan setiap aspek perkembangan anak didik.

Dalam pembelajaran matematika, metode demonstrasi adalah salah satu metode yang tepat digunakan karena penyajian data yang konkret, sehingga pemrolehan informasi oleh siswa menjadi lebih akurat. Putra (2013: 122) menjelaskan bahwa melalui metode demonstrasi verbalisme dapat dihindari karena siswa melihat dan mencobakan langsung materi pembelajaran yang disajikan guru. Dengan pengamatan dan percobaan langsung, siswa memliki kesempatan membandingkan antara teori dan kenyataan sehingga siswa akan meyakini kebenaran materi pembelajaran, terutama untuk anak usia dini yang masih belum bisa menerima informasi secara detail dan mendalam. Oleh sebab itu, metode demonstrasi tepat digunakan untuk pembelajaran yang membutuhkan prosedur dalam penyajiannya.

Secara keseluruhan, mahasiswa mampu melaksanakan metode demonstrasi di kelas selama pembelajaram matematika untuk anak usia dini dengan persentase $70 \%$. Hal ini berarti mahasiswa sudah mampu menerapkan teknik metode demonstrasi dengan cukup baik meskipun ada beberapa tahapan yang belum dilakukan seperti penjelasan kegiatan dan peragaan kegiatan kepada anak didik.

\section{Simpulan}

Berdasarkan hasil penelitian yang dilakukan, dapat diambil kesimpulan bahwa kemampuan mahasiswa menggunakan metode demonstrasi tergolong baik dengan persentase $70 \%$. Ini berarti secara umum mahasiswa sudah mampu melaksanakan metode demonstrasi di kelas sesuai dengan langkah yang telah ditetapkan. Penggunaan metode demonstrasi sangat diperlukan dalam pembelajaran matematika untuk anak usia dini, karena materi matematika yang tidak bisa hanya dijelaskan oleh guru, tetapi juga harus diperagakan dengan bantuan media pembelajaran. Semua mahasiswa PG-PAUD harus menguasai langkah dan metode demonstrasi karena 
metode ini memudahkan anak didik memahami materi yang diberikan oleh guru. Anak didik tidak hanya mendengarkan penjelasan, tetapi juga terlibat aktif dalam kegiatan.

Penulis juga mengemukakan saran- saran yaitu: (1) menjelaskan kepada mahasiswa secara detail tahapan-tahapan demonstrasi sebelum menyuruh mahasiswa melakukan kegiatan demonstrasi tersebut, (2) menggunakan metode demonstrasi dalam perkuliahan pembelajaran untuk anak usia dini secara terus menerus, dan (3) metode demonstrasi membutuhkan persiapan yang matang, sehingga mahasiswa harus mempersiapkan peralatan, bahan dan tempat yang memadai.

\section{Daftar Pustaka}

Arikunto, Suharsimi. (2008). Dasar Dasar Evaluasi Pendidikan. Jakarta: Bumi Aksara.

Cahyani, K. Anggun, I. N. Jampel, dan P. Rahayu Ujianti. (2015). Penerapan Metode Demonstrasi dalam Pengenalan Sains untuk Meningkatkan Perkembangan Kognitif Anak. Jurnal PG-PAUD Universitas Pendidikan Ganesha. Vol 3 (1) 2015.

Djamarah, Syaiful Bahri dan Aswan Zain. (2006). Strategi Belajar Mengajar. Jakarta: Rineka Cipta.

Fathurrochman, Pupuh, dan M. Sobry Sutikno. (2007). Strategi Belajar Mengajar. Jakarta: Bumi Aksara.

Hasibuan dan Mudjiono. (2013). Proses Belajar Mengajar. Bandung: PT Remaja Rosda Karya.

Putra, Sitiavaza Rizema. (2013). Desain Belajar Mengajar Kreatif Berbasis Sains. Yogyakarta: Diva Press.

Sagala, Syaiful. (2010). Supervisi Pembelajaran dalam Profesi Pendidikan. Bandung: Alfabeta.

Sanjaya, Wina. (2010). Perencanaan dan Desain Sistem Pembelajaran. Jakarta: Kencana.

Sanjaya. Wina. (2011). Perencanaan dan Desain Sistem Pembelajaran. Jakarta: Kencana.

Sartinem. (2014). Implementasi Metode Demonstrasi dengan Alat Peraga Edukatif (APE) dalam Mengenalkan Pengurangan pada Kelompok B di Bustanul Athfal 'Asyiyah Bligo 1 Ngluwar Magelang Tahun Pelajaran 2013/2014. Skripsi. Universitas Islam Negeri Sunan Kalijaga. 
Sudijono, Anas. (2005). Pengantar Statistik Pendidikan. Jakarta: RajaGrafindo Persada.

Sudjana, Nana. (2010). Dasar-dasar Proses Belajar Mengajar. Bandung: Remaja Rosda Karya.

Sujiono, Yuliani Nurani. (2008). Metode Pengembangan Kognitif. Jakarta: Universitas Negeri Terbuka.

Yusuf, Muri. (2005). Dasar-dasar dan Teknik Evaluasi Pendidikan. Padang: Universitas Negeri Padang. 